\title{
Milk production, grazing behavior and nutritional status of dairy cows grazing two herbage allowances during winter
}

\author{
Miguel Ruiz-Albarran ${ }^{1}$, Oscar Balocchi ${ }^{2}$, Fernando Wittwer ${ }^{1}$, and Rubén Pulido ${ }^{{ }^{*}}$
}

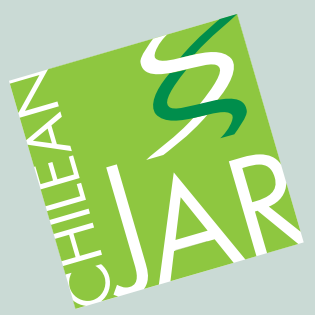

\section{ABSTRACT}

Winter grazing provides a useful means for increasing the proportion of grazed herbage in the annual diet of dairy cows. This season is characterized by low herbage growth rate, low herbage allowance, and low herbage intake and hence greater needs for supplements to supply the requirements of lactating dairy cows. The aim of this study was to determine the influence of herbage allowance (HA) offered to autumn calving dairy cows grazing winter herbage on milk production, nutritional status, and grazing behavior. The study took $63 \mathrm{~d}$ using 32 multiparous Holstein-Friesian dairy cows. Prior to experimental treatment, milk production averaged $20.2 \pm 1.7 \mathrm{~kg} \mathrm{~d}^{-1}$, body weight was $503 \pm 19 \mathrm{~kg}$, and days in milking were $103 \pm$ 6. Experimental animals were randomly assigned to two treatments according to HA offered above ground level: low $\left(17 \mathrm{~kg} \mathrm{DM} \mathrm{cow}^{-1} \mathrm{~d}^{-1}\right) v s$. high HA $\left(25 \mathrm{~kg} \mathrm{DM} \mathrm{cow}^{-1} \mathrm{~d}^{-1}\right)$. All cows were supplemented with grass silage supplying daily 6.25 and $4.6 \mathrm{~kg}$ DM of concentrate (concentrate commercial plus high corn moisture). Decreasing HA influenced positively milk production $(+25 \%)$, milk protein $(+20 \mathrm{~kg})$, and milk fat $(+17 \mathrm{~kg})$ per hectare; however no effects on milk production per cow or energy metabolic status were observed in the cows. In conclusion, a low HA showed to be the most significant influencing factor on milk and milk solids production per hectare in dairy cows grazing restricted winter and supplemented with grass silage and concentrate; but no effect on the milk production per cow was found.

Key words: Dairy, grazing behavior, nutritional status, winter grazing.

${ }^{1}$ Universidad Austral de Chile, Facultad de Ciencias Veterinarias, Casilla 567, Valdivia, Chile.

"Corresponding author (rpulido@uach.cl).

${ }^{2}$ Universidad Austral de Chile, Facultad de Ciencias Agrarias, Casilla 567, Valdivia, Chile.

Received: 3 March 2015

Accepted: 3 September 2015

doi:10.4067/S0718-58392016000100005

\section{INTRODUCTION}

Milk production in southern Chile is based on systems where calving is mainly concentrated in spring and autumn in order to meet the demand of the industry to achieve a uniform milk supply pattern throughout the year (Schöbitz et al., 2013). In the autumn system, extending the grazing season through winter until the beginning of spring provides a useful means of increasing the proportion of grazed herbage in the diet of dairy cows, reducing production cost (Pérez-Ramírez et al., 2008).

Winter grazing is characterized by low herbage growth rate, low mass herbage, and low herbage allowance (Pérez-Prieto et al., 2011a). Under these conditions, non-irrigated herbage availability usually decreases from autumn to winter as a result of weather conditions: a daily rate of growth of $0-15 \mathrm{~kg} \mathrm{DM} \mathrm{ha}^{-1}$ during winter, compared to 60-90 $\mathrm{kg} \mathrm{DM} \mathrm{ha}^{-1}$ during spring (Poff et al., 2011). Low mass herbages $\left(<2.5 \mathrm{tDM} \mathrm{ha}^{-1}\right)$ have been reported to contain higher proportions of grass leaf and lower proportions of grass stem and dead material and to be more digestible than high mass (Holmes et al., 2002). Consequently, grass development in winter is based on vegetative growth, and characterized by high concentrations of crude protein (CP) and low amounts of nonstructural carbohydrates and DM (Sotelo et al., 2012). Therefore, the factors limiting milk production under autumn-winter grazing systems are low herbage DM intake, low energy intake, and lack of synchrony in the release of nutrients in the rumen (Pulido et al., 2010; Morales et al., 2014).

In rotational grazing systems, there are two alternative management methods for grazing dairy cows that improve the supply of nutrients and rumen synchrony between energy and protein provided by the diet. The first is stimuli/motivation of herbage intake through the daily herbage allowance (Peyraud and Delagarde, 2013), and the second is by supplementation with conserved forages and concentrates (Morrison and Patterson, 2007; Reid et al., 2015). Moderately reducing the herbage allowance (HA) not only improves the efficiency of utilization of the sward, but also increases milk yield per hectare (Baudracco et al., 2010). Lower impacts on food intake and milk production by increasing HA in dairy cows grazing low mass herbage could be due to a high level of supplementation, which increases substitution rate and reduces the willingness of the cows for grazing (Pérez-Prieto et al., 2011b). The aim of this research was to evaluate, in supplemented grazing cows, the effects of a restriction on HA on milk production, grazing behavior, and nutritional status of autumn-calving dairy cows in middle lactation. 


\section{MATERIALS AND METHODS}

\section{Experimental site, animals and treatments}

The experiment was conducted at Vista Alegre Experimental Research Station of Universidad Austral de Chile (39 $47^{\prime}$ S, 7314' W; $12 \mathrm{~m}$ a.s.1.), Valdivia, Chile. The soil type corresponded to a Typic Hapludand (Valdivia Series) with flat topography. The experiment lasted $11.9 \mathrm{wk}$ winter period (19 June to 10 September 2011). Thirty-two multiparous Holstein-Friesian dairy cows from the University's dairy herd (milk yield $20.2 \pm 1.7 \mathrm{~kg} \mathrm{~d}^{-1}$; days in milk $103 \pm 6$; body weight $503 \pm 19 \mathrm{~kg}$, and body condition score $2.78 \pm 0.04$ ) were grouped according to milk yield, days in milk, and body weight. Cows were randomly assigned to two daily HA (17vs. $25 \mathrm{~kg} \mathrm{DM} \mathrm{cow}^{-1} \mathrm{~d}^{-1}$ ); all the cows were supplemented with grass silage offered at $6.25 \mathrm{~kg} \mathrm{DM} \mathrm{cow}^{-1} \mathrm{~d}^{-1}$ and $4.6 \mathrm{~kg}$ $\mathrm{DM} \operatorname{cow}^{-1} \mathrm{~d}^{-1}$ of an energetic supplementation. Animals had ad libitum access to water.

\section{Grazing and feeding management}

Grazing took place on a 13.5 ha ryegrass (Lolium perenne L.) dominant herbage with each treatment grazing on the same paddock, but separated by an electric fence according to their HA. The sward was a 20 -yr-old permanent ryegrass herbage that had been subjected to rotational grazing management. In addition, the botanical composition of the swards was composed of $40.2 \%$ L. perenne, $30.4 \%$ Bromus valdivianus Phil., 3.8\% Trifolium repens L., $10.6 \%$ weeds, and $15.4 \%$ other grasses. Cows of both treatments were kept grazing at the same paddock, but separated by an electric fence according to the correspondent daily HA. All animals had access to new herbage after each milking. The grass silage used in this study was prepared during November of the previous year from permanently improved herbages of perennial ryegrass from the same sward. Silage was offered individually to each animal after milking (08:00 and 16:00 h). The concentrate supplement was a mix of high moisture corn $(75 \%)$ and a commercial concentrate $(25 \%)$, which was offered during each milking time. A mineral mix (Ca 14.0\%, P 10.0\%, Mg $6.0 \%$, Na 4.0\%, S 0.2\%, $5000 \mathrm{mg} \mathrm{Zn} \mathrm{kg}{ }^{-1}, 1500 \mathrm{mg} \mathrm{Cu} \mathrm{kg}^{-1}$, $200 \mathrm{mg} \mathrm{I} \mathrm{kg}{ }^{-1}, 20 \mathrm{mg} \mathrm{Co} \mathrm{kg}{ }^{-1}, 14 \mathrm{mg} \mathrm{Se} \mathrm{kg}^{-1}$; Anasal Alta Producción, ANASAC, Temuco, Chile) was offered with the concentrate at a rate of $0.25 \mathrm{~kg} \mathrm{cow}^{-1} \mathrm{~d}^{-1}$.

\section{Experimental procedures and sampling}

Daily HA offer and grazing areas were adjusted daily on an herbage mass basis, estimated from 100 measurements made with rising plate meter (RPM; DairyNZ, Hamilton, New Zealand), using the following equation $Y=95 x+400$. Where $\mathrm{Y}$ is the herbage mass, 95 is the slope, $\mathrm{x}$ is the height of the herbage, and 400 is the intercept (Canseco et al., 2009). Measurements were made by walking along the paddocks in a "W" pattern, which was repeated post grazing, enabling grass disappearance of each individual herd to be calculated. Botanical composition was determined by separating each species from fresh herbage samples by hand, drying at 60 ${ }^{\circ} \mathrm{C}$ for $48 \mathrm{~h}$, and then weighing to estimate the proportion of each species in relation to the total sample dry mass.

Samples of herbages, grass silage, and concentrate were collected three times a week during the study, pooled by week, and dried for $48 \mathrm{~h}$ at $60{ }^{\circ} \mathrm{C}$. For each food, the determination of ash content, crude protein (CP) (AOAC, 1996), neutral detergent fiber (NDF) (Van Soest et al., 1991), digestible organic matter (DOM) on a DM basis (Tilley and Terry, 1963), were measured at the Animal Nutrition Laboratory of Universidad Austral de Chile. Metabolizable energy was estimated by regression using a DOM (DOM/ $\mathrm{DM} \times 100$ ), and was determined in vitro (Tilley and Terry, 1963), according to Goering and Van Soest (1970).

Cows were milked at 06:00 and 14:00 $\mathrm{h}$ and milk yield was measured at milking times during the $83 \mathrm{~d}$ of the trial. Milk fat and protein concentration were analyzed once a week by infrared spectroscopy (Milko-scan, System 4300, Foss Electric, Hillerød, Denmark). Once a week cows were weighed after morning milking and the body condition score was recorded by two experienced observers using the fivepoint scale (Ferguson et al., 1994). Coccygeal blood samples were obtained weekly from week 2 onwards after afternoon milking using vacutainers containing sodium heparin. Plasma was separated after centrifugation at $800 \times g$ for $10 \mathrm{~min}$ at $4{ }^{\circ} \mathrm{C}$, frozen, and analyzed to determine plasma concentrations of albumin (BCG, HUMAN, Wiesbaden, Germany), $\beta$-hydroxybutyrate ( $\beta$-HOB; Ranbut, Randox Laboratory, Crumlin, UK), plasma urea nitrogen (PUN) by GLDH UV (glutamate dehydrogenase) by kinetic method (UREA liquiUV, HUMAN Gesellschaft für Biochemica und Diagnostica mbH, Wiesbaden, Germany) and cholesterol (Human, CHOD-PAP (cholesterol oxidase-phenol + aminophenazone) method, nr 10017) using an auto-analyzer (Metrolab 2300, Wiener Lab, Rosario, Argentina).

Individual grazing behavior was recorded over a 24 $\mathrm{h}$ period day 45 of the trial. Observations were recorded (grazing time, ruminating time, milking time, feeding indoor time, walking time) every $10 \mathrm{~min}$ on all animals during daylight and every $15 \mathrm{~min}$ at night by four trained observers. Large numbers painted on the sides of the cows were used to support identification.

Herbage DM intake was estimated indirectly from animal performance results as follows:

Herbage DM intake $\left(\mathrm{kg} \mathrm{d}^{-1}\right)=\frac{\begin{array}{c}\left(\mathrm{ME}_{\mathrm{m}}+\mathrm{ME}_{\mathrm{my}}+\mathrm{ME}_{\mathrm{lwc}}+\mathrm{ME}_{\mathrm{g}}\right)- \\ (\text { Conc ME }+ \text { silage ME })\end{array}}{\text { Herbage ME }}$

where $\mathrm{ME}_{\mathrm{m}}, \mathrm{ME}_{\mathrm{my}}, \mathrm{ME}_{\mathrm{lwc}}$, and $\mathrm{ME}_{\mathrm{g}}$ are the metabolizable energy (ME) requirements for maintenance, milk yield, and live weight change and gestation, respectively (Baker, 2004). Conc ME and silage EM comprise the ME supplied by the concentrate supplement and grass silage $\mathrm{ME}$ is the estimated ME concentration of hand-plucked herbage samples. 


\section{Statistical analyses}

This study was a randomized block designed using Repeat Measures ANOVA. ANOVAs were carried out using the MIXED procedure of SAS (SAS Institute, Cary, North Carolina, USA). The statistical model was: $Y=\mu+H A_{i}+W_{j}$ $+\varepsilon_{i j}$. Where $Y_{i j}$ is dependent variables (milk production, $\%$ fat, $\%$ protein, $\mathrm{kg}$ fat, $\mathrm{kg}$ protein, urea, live weight, body condition), $\mu$ is intercept, $H A_{i}$ is effect of the $\mathrm{i}^{\text {th }}$ herbage allowance, $W_{k}$ is effect of the $\mathrm{k}^{\text {th }}$ week, and $\varepsilon_{i j}$ is residual of the model.

\section{RESULTS}

\section{Weather conditions, herbage and supplements characteristics}

During the experiment, the average daily temperature was $8.3{ }^{\circ} \mathrm{C}$ and the average minimum and maximum were 4.9 and $10.7^{\circ} \mathrm{C}$, respectively. Rainfall accumulated was 224.8 $\mathrm{mm}$, similar to the mean recorded during the previous 40-yr. The pre-grazing mass averaged $1400 \pm 109$ and $1340 \pm 120$ $\mathrm{kg} \mathrm{ha}^{-1} \mathrm{DM}$ for the high and low HA, respectively (Table $1)$. However, a different post-grazing mass $(\mathrm{P}>0.05)$ was registered for both treatments, averaging $935 \pm 36$ and $863 \pm$ $43 \mathrm{~kg} \mathrm{DM} \mathrm{ha}^{-1}$ for the high and low HA, respectively.

The nutritional characteristics of the herbage and supplementary feeds are presented in Table 2. Nonsignificant differences $(\mathrm{P}>0.05)$ were found in the chemical composition of the herbage for the treatments, showing higher concentrations of $\mathrm{CP}, \mathrm{ME}$, and lower content of DM. The silage supplemented had a high concentration of DM, $\mathrm{CP}$, and NDF and the concentrate had low protein and fiber concentration and high energy.

\section{Animal performance, plasma metabolites and feeding behavior}

Feed intake data are presented in Table 3. Decreasing HA from 25 to $17 \mathrm{~kg} \mathrm{DM} \mathrm{cow}^{-1} \mathrm{~d}^{-1}$, did not reduce herbage DMI and total DMI $(\mathrm{P}>0.05)$. The total grazing time (195 and

Table 1. Pre grazing, post-grazing mass, herbage utilization of dairy cows grazing two winter herbage allowances.

\begin{tabular}{lccccc}
\hline \multicolumn{5}{c}{$\begin{array}{c}\text { Herbage } \\
\text { allowance }\end{array}$} & \\
\cline { 2 - 4 } & High & Low & SEM & Significance \\
\hline Pre-grazing herbage mass, kg DM ha ha $^{-1(1)}$ & 1400 & 1340 & 120 & 0.142 \\
Post-grazing herbage mass, kg DM ha & $935 \mathrm{a}$ & $863 \mathrm{~b}$ & 41 & 0.001 \\
Herbage utilization, \% & 33 & 36 & 4.6 & 0.132 \\
Stocking rate cows, ha d & -1 & $56 \mathrm{a}$ & $78 \mathrm{~b}$ & 5.8 & 0.001 \\
\hline
\end{tabular}

High $=25$, Low $=17 \mathrm{~kg} \mathrm{DM} \mathrm{cow}^{-1} \mathrm{~d}^{-1}$, SEM: standard error of the mean. ${ }^{1}$ Equation to estimate the herbage mass: $\mathrm{Y}=95 \mathrm{x}+400\left(\mathrm{R}^{2}=0.77\right), \mathrm{Y}=$ Herbage mass $\left(\mathrm{kg} \mathrm{DM} \mathrm{ha}^{-1}\right), \mathrm{x}=$ compressed height measured with the plate (Canseco et al., 2009).

Values in the same row not sharing a common letter are significantly different according to Tukey test.
Table 2. Chemical composition of dietary feeds offered to cows grazing two winter herbage allowances.

\begin{tabular}{|c|c|c|c|c|c|}
\hline & \multicolumn{2}{|c|}{$\begin{array}{l}\text { Herbage } \\
\text { allowance }\end{array}$} & \multirow[b]{2}{*}{$\begin{array}{l}\text { Grass } \\
\text { silage }\end{array}$} & \multicolumn{2}{|c|}{ Supplements } \\
\hline & High & Low & & $\begin{array}{l}\text { High } \\
\text { moisture } \\
\text { corn }\end{array}$ & Concentrate \\
\hline $\mathrm{DM}, \mathrm{g} \mathrm{kg}^{-1}$ & 126 & 124 & 480 & 682 & 842 \\
\hline $\mathrm{CP}, \mathrm{g} \mathrm{kg}^{-1} \mathrm{DM}$ & 271 & 273 & 175 & 74 & 207 \\
\hline ME, Mcal kg-1 DM & 2.80 & 2.87 & 2.47 & 3.25 & 2.92 \\
\hline $\mathrm{NDF}, \mathrm{g} \mathrm{kg}^{-1} \mathrm{DM}$ & 417 & 387 & 562 & 71 & 185 \\
\hline $\mathrm{ADF}, \mathrm{g} \mathrm{kg}^{-1} \mathrm{DM}$ & 253 & 235 & 324 & 252 & 63 \\
\hline $\mathrm{EE}, \mathrm{g} \mathrm{kg}^{-1}$ & 24.1 & 25.9 & 29.6 & 41.1 & 29.3 \\
\hline $\mathrm{VD}, \mathrm{g} \mathrm{kg}^{-1}$ & 774 & 794 & 675 & 914 & 822 \\
\hline $\mathrm{N}-\mathrm{NH}_{3}$ & - & - & 7.39 & - & - \\
\hline $\mathrm{pH}$ & - & - & 4.54 & - & - \\
\hline
\end{tabular}

High $=25$, Low $=17 \mathrm{~kg} \mathrm{DM} \mathrm{cow}^{-1} \mathrm{~d}^{-1},-$ : values not determined.

DM: Dry matter, CP: crude protein, ME: metabolizable energy, NDF: neutral detergent fiber, ADF: acid detergent fiber, EE: ether extract, $\mathrm{N}-\mathrm{NH}_{3}$ : ammonia $\mathrm{N}$

Table 3. Feed intake and grazing behavior for cows grazing two winter herbage allowances.

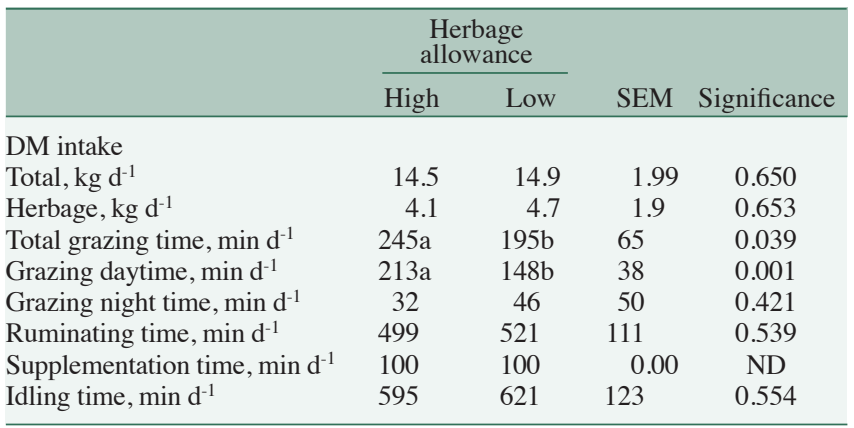

High $=25$, Low $=17 \mathrm{~kg} \mathrm{DM} \mathrm{cow}{ }^{-1} \mathrm{~d}^{-1}$, SEM: standard error of the mean. Values in the same row not sharing a common letter are significantly different according to Tukey test.

245 min d $^{-1}$ for low and high HA, respectively) and grazing time during day light $\left(148,213 \mathrm{~min} \mathrm{~d}^{-1}\right.$, for low and high HA, respectively) were different $(\mathrm{P}<0.05)$. The remaining time was used in the remaining activities, such eating supplement, milking and idling.

The effect of the two HA on milk production and composition are shown in Table 4. Milk production, milk persistency, fat, and milk protein concentration showed nonsignificant differences between the two HA $(\mathrm{P}>0.05)$. Milk urea concentration was lower when cows were grazing the low HA rather than high HA. The high HA treatment showed a lower milk urea concentration. Decreasing HA influenced positively milk production $(+25 \%)$, milk protein $(20 \mathrm{~kg})$ and milk fat $(17 \mathrm{~kg})$ per hectare, however no effects on milk production per cow were observed in the cows. The values of plasma concentrations of $\beta$-HOB, urea, and cholesterol are shown in Table 5. No differences were found for $\beta$-HOB concentrations $(\mathrm{P}>0.05)$. The high HA generated lower concentrations of urea during the experiment $(\mathrm{P}<0.05)$. 
Table 4. Milk performance and milk composition for cows grazing two winter herbage allowances.

\begin{tabular}{|c|c|c|c|c|}
\hline & \multicolumn{2}{|c|}{ Herbage allowance } & \multirow[b]{2}{*}{ SEM } & \multirow[b]{2}{*}{ Significance } \\
\hline & High & Low & & \\
\hline Milk production, $\mathrm{kg} \mathrm{d}^{-1}$ & 19.6 & 20.2 & 0.113 & 0.103 \\
\hline Milk production, $\mathrm{kg} \mathrm{ha}^{-1}$ & $1139 b$ & $1518 \mathrm{a}$ & 14.87 & 0.001 \\
\hline Milk persistency, $\mathrm{kg} \mathrm{d}^{-1}$ & 0.012 & 0.014 & 0.0007 & 0.289 \\
\hline Fat, $\%$ & 4.6 & 4.6 & 0.268 & 0.983 \\
\hline Protein, \% & 3.4 & 3.5 & 0.067 & 0.148 \\
\hline Fat, $\mathrm{kg} \mathrm{ha}^{-1}$ & $52 b$ & $69 a$ & 0.683 & 0.001 \\
\hline Protein, $\mathrm{kg} \mathrm{ha}^{-1}$ & $39 b$ & $59 \mathrm{a}$ & 0.524 & 0.001 \\
\hline Urea, mmol L-1 & $5.6 \mathrm{a}$ & $4.4 \mathrm{~b}$ & 0.362 & 0.017 \\
\hline
\end{tabular}

High $=25$, Low $=17 \mathrm{~kg}$ DM cow-1 d $\mathrm{d}^{-1}$, SEM: standard error of the mean .

Values in the same row not sharing a common letter are significantly different according to Tukey test.

Table 5. Body weight, body condition score and blood metabolites for cows grazing two winter herbage allowances.

\begin{tabular}{|c|c|c|c|c|}
\hline & \multicolumn{2}{|c|}{ Herbage allowance } & \multirow[b]{2}{*}{ SEM } & \multirow[b]{2}{*}{ Significance } \\
\hline & High & Low & & \\
\hline \multicolumn{5}{|l|}{ Body weight } \\
\hline Start, $\mathrm{kg}^{-1}$ & 503 & 501 & 19 & 0.947 \\
\hline Change, $\mathrm{kg}^{-1}$ & 0.578 & 0.679 & 0.454 & 0.678 \\
\hline \multicolumn{5}{|l|}{$\begin{array}{l}\text { Body condition score scale } \\
\text { (1 to } 5)\end{array}$} \\
\hline Start & 2.78 & 2.75 & 0.032 & 0.451 \\
\hline Change & -0.001 & -0.005 & 0.0071 & 0.129 \\
\hline \multicolumn{5}{|l|}{ Blood metabolites } \\
\hline$\beta$-Hydroxibutyrate, $\mathrm{mmol} \mathrm{L}^{-1}$ & 1.24 & 1.24 & 0.089 & 0.997 \\
\hline Urea, $\mathrm{mmol} \mathrm{L}^{-1}$ & 6.12 & 6.36 & 0.224 & 0.427 \\
\hline Albumin, $\mathrm{g} \mathrm{dL}^{-1}$ & 41.7 & 40.8 & 0.037 & 0.106 \\
\hline Cholesterol, mmol L-1 & 4.23 & 4.27 & 0.141 & 0.867 \\
\hline
\end{tabular}

High $=25$, Low $=17 \mathrm{~kg} \mathrm{DM}$ cow- $1 \mathrm{~d}^{-1}$, SEM: standard error of the mean.

\section{DISCUSSION}

\section{Weather conditions, herbage and supplements characteristics}

The weather conditions (average temperature and rainfall) of the previous summer induced a decrease in growth rate of grass, resulting in low availability of herbage during autumn. As expected from our previous research (Pulido et al., 2010; Schöbitz et al., 2013), pre-grazing herbage characteristics were similar for the treatments (Table 1), but lower than that reported by Hernandez-Mendo and Leaver (2004) and Pulido et al. (2010), $1800 \mathrm{~kg} \mathrm{DM} \mathrm{ha}{ }^{-1}$, though higher than the amount reported by Pérez-Prieto et al. (2011a). In this region, dairy cows graze all year round, therefore, to wait for pre-grazing herbage mass conditions similar to those reported by Pulido et al. (2010) during spring would mean keeping the animals out of grazing for a long period, which is not possible. It has been reported that decreasing HA, but keeping constant pre-grazing herbage mass, increases sward utilization; therefore, a greater number of cows can be sustained on the same herbage and hence improving milk production per hectare (Baudracco et al., 2010; Peyraud and Delagarde, 2013). In our study, sward utilization was lower in both HA which is expected in these grazing conditions, where cows have restricted their capacity to grazing, and therefore, the DM intake of herbage is less than $40 \%$ of the herbage offered. There was a difference on stocking rate between the two HA $(\mathrm{P}<0.05)$; decreasing HA, increased by $28.5 \%$ the number of cows $\left(\mathrm{ha}^{-1} \mathrm{~d}^{-1}\right)(\mathrm{P}<0.05)$.

The effect of weather condition is reflected in the chemical composition of the herbage throughout the different growing seasons. Temperate herbages used for dairy cows are described as high quality when chemical composition is around $180-240 \mathrm{~g} \mathrm{DM} \mathrm{kg}^{-1}, 180$ to $250 \mathrm{~g} \mathrm{CP} \mathrm{kg}^{-1} \mathrm{DM}, 400$ to $500 \mathrm{~g} \mathrm{NDF} \mathrm{kg}^{-1} \mathrm{DM}$, and 2.5 to 2.9 Mcal ME kg-1 DM (Clark and Kanneganti, 1998). The nutritive value (Table 2) of the pre-grazing herbages mass was similar to those described by Sotelo et al (2012) showing higher concentrations of CP (270 $\left.\mathrm{g} \mathrm{kg}^{-1} \mathrm{DM}\right)$ and ME (2.83 Mcal kg-1 DM) and lower DM content $\left(125 \mathrm{~g} \mathrm{~kg}^{-1} \mathrm{DM}\right)$. All these values are representative of winter herbages in Southern Chile (Balocchi and López, 2009; Pulido et al., 2015). Traditionally, grazing dairy cows generally are supplemented with grass silage during autumn and winter, and it has shown to increase total DMI and maintain milk production under restricted grazing conditions (Kennedy et al., 2011; Reid et al., 2015). Diets based on grass silage are characterized by a high level of fast degraded $\mathrm{CP}$ in the rumen and by being unable to improve rumen synchrony between energy and protein from the diets. Therefore, the supply of carbohydrates throughout an energetic concentrate is important for the rumen microbial metabolism due to their capacity to modify molar proportions of volatile fatty acids (Pulido et al., 2009), enhancing propionate concentrations, the most relevant precursor of glucose in ruminants, and therefore positively influences the energy metabolic status in the cow (Hall and Huntington, 2008).

\section{Animal performance, plasma metabolites and feeding behavior}

The lack of response in milk production could be related to the similar intakes of nutrients, in quality and quantity, obtained from the two HA (Tables 2, 3, and 4). Kennedy et al. (2008) also did not find an effect of the HA on milk production in cows at the beginning and middle of lactation (40, 80, and $120 \mathrm{~d}$ in milk), evaluating HA of 13, 16, and 19 $\mathrm{kg} \mathrm{DM}$ (measured $>4 \mathrm{~cm}$ height). However, Pérez-Prieto et al. (2011a) found that decreasing HA from 32 to $19 \mathrm{~kg}$ DM $\operatorname{cow}^{-1} \mathrm{~d}^{-1}$ (measured $>0 \mathrm{~cm}$ ), milk yield decreased by $0.10 \mathrm{~kg}$ $\mathrm{kg}^{-1} \mathrm{HA}$; which could be due to a reduction on herbage DM intake because in this research, a greater pre-grazing herbage mass (2300 kg OM ha-1 above ground level) was included, compared with the HA offered in our research. Therefore reducing HA increases milk production per hectare $(+25 \%)$ without changing milk production per cow $(\mathrm{P}>0.05)$, since HAs offered were similar without affecting animal performance.

The similar concentration of milk fat is in agreement with the findings of Kennedy et al. (2008) and may be explained 
by the adequate NDF intake of the cows grazing the two HA. The lack of variation in milk protein concentrations between the treatments could be a consequence of null variation in energy supply. However, the superior milk urea N (MUN) observed in the high HA $(\mathrm{P}<0.05)$ may have occurred because of the higher $\mathrm{CP}$ intake from the herbages, caused by grazing short swards in a vegetative state. Previous results (Schöbitz et al., 2013) have shown that paddocks grazed with high HA had more dead material than when a low HA was used. Only when grass is grazed at low mass (1.5-2.0 t DM ha ${ }^{-1}$ ), concentrations of $\mathrm{CP}$, energy and soluble carbohydrates are higher, therefore, the superior MUN concentration suggested that an increase in herbage selectivity could occur by increasing HA, even though no effect on herbage intake was observed.

An indication of the balance between nutrient supply and requirements for energy and protein is obtained by measuring the concentration of blood metabolites (Wittwer, 2012). The plasma concentration of $\beta$-HOB was above the upper reference limit $\left(<0.6 \mathrm{mmol} \mathrm{L}^{-1}\right)$. The healthy condition of the cows, as well as the lactation period, was not compatible with clinical or subclinical ketosis. Therefore, the increase of plasma $\beta$-HOB would appear to be induced by butyrate absorption from the rumen, related to the butyric acid contained in the silage supplemented (Ruiz-Albarrán et al., 2012). A high urea concentration in plasma or milk indicates high rumen ammonia concentration, with excess of ammonia passing into the blood stream and being converted to urea by the liver. The plasma urea concentrations were similar for both treatments and within the reference interval (2.6 to $7.0 \mathrm{mmol} \mathrm{L}^{-1}$ ) (Wittwer, 2012), which indicates a ruminal synchrony between energy/protein, and associated with a high content of degradable protein in the diet. Plasma cholesterol concentration was similar in cows grazing the two HA, and which may be associated with a higher production of ruminal acetate and butyrate as a consequence of a relatively higher intake of silage in the diet (Chamberlain and Wilkinson, 1996).

On low-mass herbage, dairy cows try to maintain herbage intake by increasing grazing time, but in the presence of a very short sward cows are unable to fully compensate the reduction of intake rate and the total daily intake is reduced (Peyraud and Delagarde, 2013). Decreasing HA from 25 to 17 $\mathrm{kg} \mathrm{DM} \mathrm{cow}{ }^{-1} \mathrm{~d}^{-1}$, did not reduces herbage DMI and total DMI $(\mathrm{P}>0.05)$ (Table 3). This is consistent with milk production and with the similar intake of nutrients, in quantity and quality found for both HA (Tables 4, 2, and 1, respectively). In addition, supplementary preserved forages such as grass silage and concentrates are needed to maintain total DMI when offered as buffer food for a short period of the day. The grazing dairy cow responds by adjusting its eating behavior in terms of bite rate, chewing rate, bite mass, and intake rate to satisfy its nutritional requirements under circumstances imposed by herbage, management and environment (Pulido and Leaver, 2001). The total grazing time (195 and 245 min $\mathrm{d}^{-1}$ for low and high HA, respectively) and grazing time during day light $\left(148,213 \mathrm{~min} \mathrm{~d}^{-1}\right.$, for low and high HA, respectively) were different $(\mathrm{P}<0.05)$. The remaining time was used in the remaining activities, such eating supplement, milking and idling. In contrast, grazing time is normally around 450 or $320 \mathrm{~min} \mathrm{~d}^{-1}$ in dairy cows producing $15-25$ $\mathrm{kg}$ milk $\mathrm{d}^{-1}$ under rotational grazing in spring or in autumn (Pulido et al., 2010; Schöbitz et al., 2013). The grazing time recorded in the present study was also lower than reported by Kennedy et al. (2011), Hernandez-Mendo and Leaver (2004), and Pérez-Prieto et al. (2011a) for dairy cows under restricted access time at herbage, and receiving conserved forages (maize silage or grass silage). This difference could be due to greater pre-grazing herbage mass in their works, which probably increased the willingness of the cows for grazing. The lower grazing time for both HA offered in this research could be consequence of dairy cows stop grazing due to a physical limitation imposed by the herbage; since they cannot easily graze due to the reduced height of the herbage (Pérez-Prieto et al., 2011a). Grazing time does not appear as an adjustable variable to increasing herbage intake of dairy cows grazing on low herbage mass. The changes in the eating behavior could be observed in the cows grazing on the low HA (Table 3), showing lower grazing time than the time needed by those grazing on the high HA.

\section{CONCLUSIONS}

Winter grazing herbage allowance (HA) can be directly related to farmer decision; where offering a high HA could constitute a waste of resources and may increase the need for herbage and land; this intervention seems to be much less attractive when the sensible objective is to increase milk production per hectare. The present study concluded that a lower HA in dairy cows grazing two winter HA showed a better herbage utilization, greater milk and milk solid productions per hectare, without affecting milk production per cow or the energy and protein metabolic status of the cows. Under winter grazing, decreasing HA decreased the willingness of the cow for grazing, without affecting herbage intake and milk production per cow.

\section{ACKNOWLEDGEMENTS}

This project was financed by FONDECYT 1100513.

\section{REFERENCES}

AOAC. 1996. Official methods of analysis. $16^{\text {th }}$ ed. Association of Official Analytical Chemists (AOAC), Gaithersburg, Maryland, USA.

Baker, R.D. 2004. Estimating herbage intake from animal performance. In Penning, PD. (ed.) Herbage intake handbook. British Grassland Society, Reading, UK.

Balocchi, O.A., and I.F. López. 2009. Herbage production, nutritive value and grazing preference of diploid and tetraploid perennial ryegrass cultivars (Lolium perenne L.) Chilean Journal of Agricultural Research 69:331-339. 
Baudracco, J., N. Lopez-Villalobos, C.W. Holmes, and K.A. Macdonald. 2010. Effects of stocking rate, supplementation, genotype and their interactions on grazing dairy systems: a review. New Zealand Journal of Agricultural Research 53:109-133.

Canseco, C., A. Abarzúa, J. Parga, N. Teuber, O. Balocchi, J. Lopetegui, et al. 2009. Calidad nutritiva de las praderas. p. 5167. In Teuber, N., O. Balocchi, and J. Parga (eds.) Manejo del pastoreo. Fundación para la Innovación Agraria (FIA), Osorno, Chile.

Chamberlain, A.T., and J.M. Wilkinson (eds.) 1996. Feeding the dairy cow. 241 p. Chalcombe Publications, Shedfield, UK.

Clark, D.A., and V.R. Kanneganti. 1998. Grazing management systems for dairy cattle. 331 p. In Cherney, J.H., and D.J.R. Cherney (eds.) Grass for dairy cattle. CAB International, Wallingford, UK.

Ferguson, J.D., D.T. Dalligan, and N. Thomsen. 1994. Principal descriptors of body condition in Holstein dairy cattle. Journal of Dairy Science 77:2695-2703.

Goering, H.K, and P.J. Van Soest. 1970. Forage fiber analysis (apparatus, reagents, procedures, and some applications). Agriculture Handbook 379. 20 p. United States Department of Agriculture, Washington, D.C., USA.

Hall, M.B., and G.B. Huntington. 2008. Nutrient synchrony: Sound in theory, elusive in practice. Journal of Animal Science 86:287-292.

Hernandez-Mendo, O., and J.D. Leaver. 2004. Effect of replacing time available from grazing with time available for eating maize silage and soybean meal on milk yield and feeding behavior in dairy cows. Grass and Forage Science 59:318-330.

Holmes, C.W., I.M. Brookes, D.J. Garrick, D.D.S. Mackenzie, T.J. Parkinson, and G.F. Wilson. 2002. Milk production from pasture. Principles and practices. 602 p. Massey University, Palmerston North, New Zealand.

Kennedy, E., J. Curran, B. Mayes, M. McEvoy, J.P. Murphy, and M. O'Donovan. 2011. Restricting dairy cow access time to pasture in early lactation: the effects on milk production, grazing behaviour and dry matter intake. Animal 5:1805-1813.

Kennedy, E., M. O'Donovan, L. Delaby, and F.P. O'Mara. 2008. Effect of herbage allowance and concentrate supplementation on dry matter intake, milk production and energy balance of early lactating dairy cows. Livestock Science 117:275-286.

Morales, A., D. Grob, O. Balocchi, and R. Pulido. 2014 Productive and metabolic response to two levels of corn silage supplementation in grazing dairy cows in early lactation during autumn. Chilean Journal of Agricultural Research 74:205-212.

Morrison, S.J., and D.C. Patterson. 2007. The effects of offering a range of forage and concentrate supplements on milk production and dry matter intake of grazing dairy cows. Grass and Forage Science 62:332-345

Pérez-Prieto, L., J.L. Peyraud, and R. Delagarde. 2011a. Pasture intake, milk production and grazing behaviour of dairy cows grazing low-mass pastures at three daily allowances in winter. Livestock Science 137:151-160.

Pérez-Prieto, L.A., J.L. Peyraud, and R. Delagarde. 2011b. Substitution rate and milk yield response to corn silage supplementation of late-lactation dairy cows grazing low-mass pastures at two daily allowances in autumn. Journal of Dairy Science 94:3592-3604.
Pérez-Ramírez, E., R. Delagarde, and L. Delaby. 2008. Herbage intake and behavioural adaption of grazing dairy cows by restricting time at pasture under two feeding conditions. Animal 2:1384-1392.

Peyraud, J.L., and R. Delagarde. 2013. Managing variations in dairy cow nutrient supply under grazing. Animal 7:57-67.

Poff, A.J., O. Balocchi, and I. López. 2011. Sward and tiller growth dynamics of Lolium perenne $\mathrm{L}$. as affected by defoliation frequency during autumn. Crop and Pasture Science 62:346-354

Pulido, R.G., and J.D. Leaver. 2001. Quantifying the influence of sward height, concentrate level and initial milk yield on the milk production and grazing behaviour of continuously stocked dairy cows. Grass and Forage Science 56:57-67.

Pulido, R., R. Muñoz, C. Jara, O. Balocchi, J.P. Smulders, F. Wittwer, et al. 2010. The effect of pasture allowance and concentrate supplementation type on milk production performance and dry matter intake of autumn-calving dairy cows in early lactation. Livestock Science 132:119-125.

Pulido, R.G., R. Muñoz, P. Lemarie, F. Wittwer, P. Orellana, and G.C. Waghorn. 2009. Impact of increasing grain feeding frequency on production of dairy cows grazing pasture. Livestock Science 125:109-114.

Pulido, R.G., M. Ruiz-Albarrán, O.A. Balocchi, P. Nannig, and Fernando Wittwer. 2015. Effect of timing of pasture allocation on production, behavior, rumen function, and metabolism of early lactating dairy cows during autumn. Livestock Science 177:43-51.

Reid, M., M. O’Donovan, J.P. Murphy, C. Fleming, E. Kennedy, and E. Lewis. 2015. The effect of high and low levels of supplementation on milk production, nitrogen utilization efficiency, and milk protein fractions in late-lactation dairy cows. Journal of Dairy Science 98:5529-5544.

Ruiz-Albarrán, M., O.A. Balocchi, M. Noro, F. Wittwer, and R.G. Pulido. 2012. Effect of increasing pasture allowance and grass silage on animal performance, grazing behaviour and rumen fermentation parameters of dairy cows in early lactation during autumn. Livestock Science 150:407-413.

Schöbitz, J., M. Ruiz-Albarrán, O.A. Balocchi, F. Wittwer, M. Noro, and R.G. Pulido. 2013. Effect of increasing pasture allowance and concentrate supplementation on animal performance and microbial protein synthesis in dairy cows. Archivos de Medicina Veterinaria 45:247-258.

Sotelo, J., M. Noro, F. Wittwer, J.P. Smulders, and R.G. Pulido. 2012. Evaluation of the herbage allowance and type of concentrate on some ruminal parameters of grazing dairy cows during autumn. Archivos de Medicina Veterinaria 44:167-172.

Tilley, J., and R. Terry. 1963. A two stages technique for the in vitro digestion of forage crops. Journal of British Grassland Society 18:104-111

Van Soest, P.J., J.B. Robertson, and B.A. Lewis. 1991. Methods for dietary fiber, neutral detergent fiber and non-starch polysaccharides in relation to animal nutrition. Journal of Dairy Science 74:3583-3597.

Wittwer, F. 2012. Manual de patología clínica veterinaria. $2^{\mathrm{a}}$ ed. 200 p. Universidad Austral de Chile, Valdivia, Chile. 